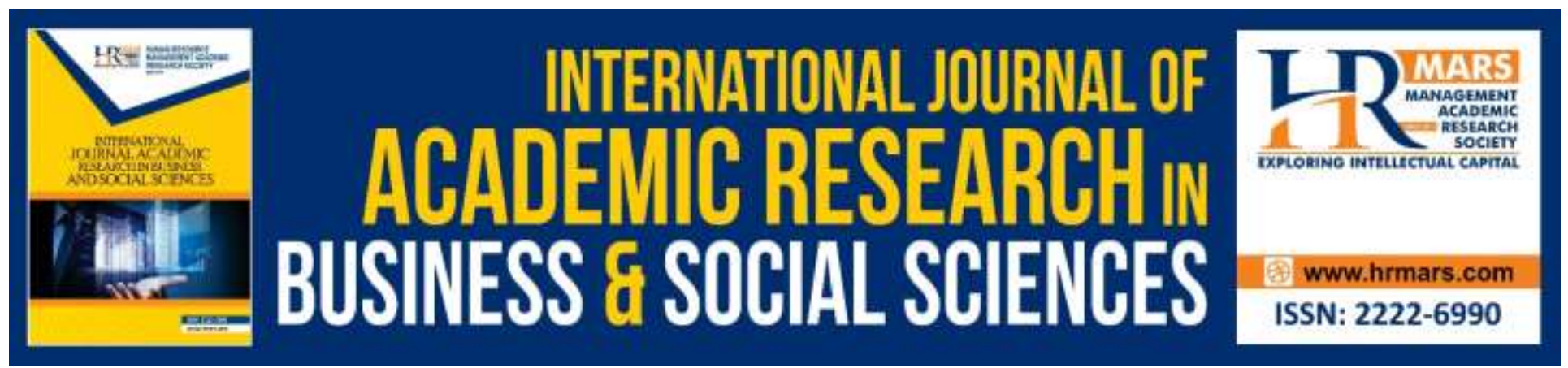

\title{
Social Communication Skills' Criteria for Placement of Student with Disabilities in Inclusive Program
}

Norfishah Mat Rabi, Wong Kun Teck, Noralizawati Abdullah, Nur Attirra Wanni Mohd Nasir, Nurul Shahida Nordin

To Link this Article: http://dx.doi.org/10.6007/IJARBSS/v10-i3/7079

DOI:10.6007/IJARBSS/v10-i3/7079

Received: 01 February 2020, Revised: 22 February 2020, Accepted: 12 March 2020

Published Online: 24 March 2020

In-Text Citation: (Rabi et al., 2020)

To Cite this Article: Rabi, N. M., Teck, W. K., Abdullah, N., Nasir, N. A. W. M., \& Nordin, N. S. (2020). Social Communication Skills' Criteria for Placement of Student with Disabilities in Inclusive Program. International Journal of Academic Research in Business and Social Sciences, 10(3), 645-655.

Copyright: @ 2020 The Author(s)

Published by Human Resource Management Academic Research Society (www.hrmars.com)

This article is published under the Creative Commons Attribution (CC BY 4.0) license. Anyone may reproduce, distribute, translate and create derivative works of this article (for both commercial and non-commercial purposes), subject to full attribution to the original publication and authors. The full terms of this license may be seen

at: http://creativecommons.org/licences/by/4.0/legalcode

\section{Vol. 10, No. 3, 2020, Pg. 645 - 655}

Full Terms \& Conditions of access and use can be found at http://hrmars.com/index.php/pages/detail/publication-ethics 


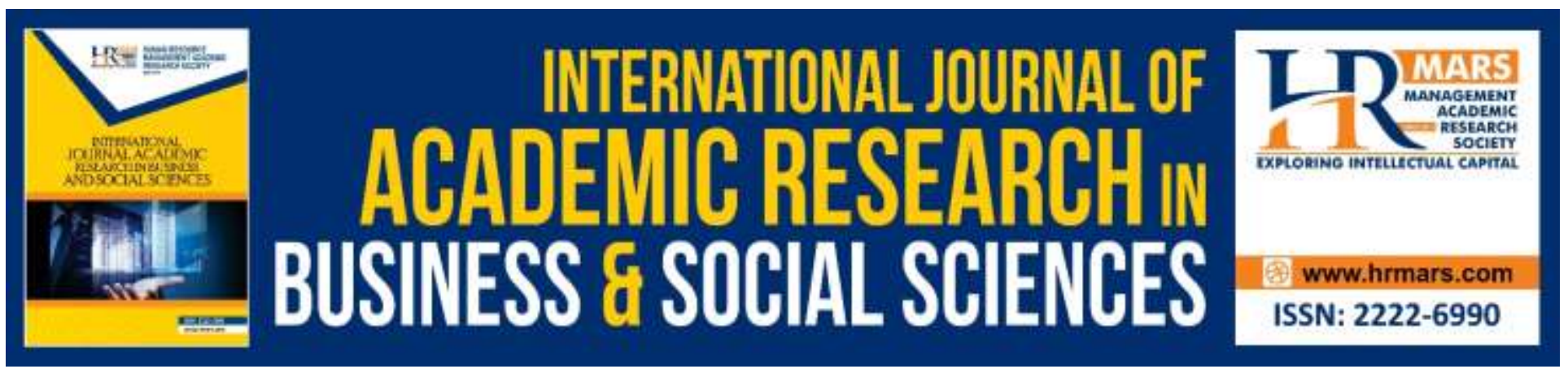

\title{
Social Communication Skills' Criteria for Placement of Student with Disabilities in Inclusive Program
}

\author{
Norfishah Mat Rabi, Wong Kun Teck, Noralizawati Abdullah, Nur \\ Attirra Wanni Mohd Nasir, Nurul Shahida Nordin \\ Faculty of Human Development, Universiti Pendidikan Sultan Idris, Malaysia
}

\begin{abstract}
This study is conducted to determine the criteria of social communication skills for placement of student with disabilities in inclusive program. This qualitative study involved 25 special education teachers and 25 mainstream teachers. The required data were collected using an interview with teachers and was analyzed qualitatively involving transcribing, coding and thematic. Items in checklist were developed based on the interview data. The checklist were given to the experts to validate and after detailed analysis, a list of items were finally determined. Findings proven that verbal communication, non-verbal communication, speech ability, and social interaction are important to be assessed for the placement of student in the inclusive program. For the achievement of learning outcome, those skills need to give prior attention by teachers and school. As preparation, it is necessary to teach the appropriate social communication skills which will allows students to practice and apply the social communication strategies and skills in learning environments and personal life. In addition, social communication are considered as one of the important skills for the success or failure in education intrinsically, especially for the student with disabilities.
\end{abstract}

Keyword: Inclusive Program, Social Communication Skills, Student with Disabilities

\section{Introduction}

An ability in social communication would be a criteria to put into consideration for successful education beside academic achievements. For student with disabilities, communication is an essential skill to be acquired in order to be socialized with others. But most of them have difficulties in communication skill as example students identified with intellectual disabilities or autism characteristically have limited skills to interact effectively with teachers and peers (Huges, 2011). Communication skill is a two-way process in which participants exchange information, ideas, feelings, and opinions. It is vitally important, as it is one of the most basic elements of human functioning, and is the cornerstone of strong, healthy interpersonal relationships (Erozkan, 2013). Whereas, social skills are behaviors enabling individuals to interact influentially and to abstain from undesirable responses and represent the individuals' social and behavioral health success (Rawles, 2016). These 
skills include behaviors such as pioneering in the establishment of new communications, requesting help, and making suggestions to help others. Atashak, Baradaran, and Ahmadvand (2013) proposed that social skills, including some behaviors that are applied in successful and appropriate interactions with others, emerge from having a social foundation and cognition, such as social perception and reasoning. But these skill can be learned by student with disabilities effectively if they are given chances to join in the formal education.

Verbal communication, non-verbal communication, speech ability, and social interaction are some examples of this social and communication skills (Norfishah, 2019). Majority of student with disabilities do not acquire these skills, which is why most of these student encounter negative response from adults or other children, and these problem affected their learning process in the classroom. According to Karakaya, \& Taufan (2018), the problem occurred because while teachers worked together with inclusion students, they did not interact with them sufficiently. De Bortoli, Arthur-Kelly, Mathisen, and Balandin (2014) stated that children with moderate to severe disabilities often show delays in their language acquisition and they have difficulty engaging in communicative interactions. In helping student with disabilities success in education setting, understanding student communication skill must be done systematically through a comprehensive screening instrument. The assessment without the proper instrument will produce a result with little evidence.

\section{Literature Review}

In Malaysia, formal education is highly recommended for student with disabilities as mentioned in national educational plan. They should be given an opportunity whether in special education class or in the inclusive setting. Inclusive setting involves children learning together, in the context where each individual is valued and is actively engaged in what is learnt and what is taught (Spratt \& Florian, 2013). In the formal education, student have an opportunity to well socialized with peers which is good for the development of social communication skill. Research done by Aoife Smith, Paula Prendeville \& Kinsella (2018) suggests that in order for true inclusion to take place, students must participate socially with their peers, outside the classroom space. The central idea of formal education especially in inclusive setting is that all students have equal opportunities to develop their abilities and talents individually and in cooperation with others (Bjornsrud \& Nilsen, 2011), which leads to a higher level of all dimensions of educational quality of effectiveness, efficiency, equality, relevance and sustainability.

Inclusive education is provided for children with diverse abilities in all aspects of schooling, involves regular schools and classrooms genuinely adopting and changing to meet the needs of all children differences. Placement of student in the inclusive setting must be done systematically but it is not easy to do so. As mention by Sakiz (2018), referral and identification was often carried out with little consideration of preventive and holistic approaches; (b) identification based on narrow assessment guided the educational content, influenced school climate and teacher practices and (c) school management bodies assumed little responsibility to plan, coordinate and evaluate the education provided to students with learning disabilities. Most of students with special education needs (SEN) lack skills needed to master the mainstream classroom course content, that they are disruptive to other students in the class, and that only special schools are able to ensure their learning and development (de Boer, Pijl \& Minnaert 2011; Hansen, 2012). Students with special education needs (SEN) also showed several emotional and behavioral disabilities (EBD) that influenced their 
INTERNATIONAL JOURNAL OF ACADEMIC RESEARCH IN BUSINESS AND SOCIAL SCIENCES Vol. 10, No. 3, March, 2020, E-ISSN: 2222-6990 @ 2020 HRMARS

learning environment in the mainstream classroom but nevertheless, there is little research that explores how students with EBD can succeed within general education classrooms (Naraian, Ferguson, \& Thomas, 2012).

Student with disabilities are known having problem in social communication in the context of interpersonal and intrapersonal. De Bortoli, Arthur-Kelly, Mathisen, and Balandin (2014) stated that children with moderate to severe disabilities often show delays in their language acquisition and they have difficulty engaging in communicative interactions. This statement is supported by Karakaya, \& Taufan (2018) that inclusion students were found to have moderate social skills and high level of problem behaviors. If they are lack of social communication skills, how could they survive in the inclusive classroom even though they are well performed in academic. Social communication skill play a key factor in successful inclusion of student with disabilities together with the typical children. As in student with special needs, delays in functional communication often co-occur with fewer opportunities for pro-social interactions with peers (Ferraioli \& Harris, 2011). Social skills are a collection of learned behaviors giving the individual the ability to have an influential relationship with others and to abstain from socially unreasonable reactions (Agran, Hughes, Thoma, \& Scott, 2016; Davies, Cooper, Kettler \& Elliott, 2015; Gresham, 2016).

\section{Methodology}

This qualitative study examines specifically on the determining a set of criteria in social communication skill of student with disabilities for placement in inclusive program. This study uses purposive sampling. The sample of the study is 50 teachers at two primary schools in rural district of Malaysia. 25 special education teachers and 25 mainstream teachers were selected as a participant for this study. For data collection, this study used interviews and analysis of document. An interview session was conducted individually and focus groups with special education and mainstream teachers for five times. Interview data was analyzed qualitatively involving transcribing, coding and thematic. Other instruments used in collecting data were field notes, video recordings and checklist. Findings from the interview data were used to develop a checklist. The checklist then was given to the expert to validate. After detailed analysis, a list of items were finally determined. For trial assessment, the checklist were given to the respondent ( 25 special education teachers and 25 mainstream teachers) to identify the strength and the weaknesses of the items. Data from the checklist was analyzed and reported descriptively and supported by reference statistics. Four aspect of data collection focused on social communication skill including social interaction, verbal communication, non-verbal communication and speech ability.

\section{Results}

The importance criteria in social communication skills for student with disabilities were explained by participants involving 50 teachers ( 25 special education teachers and 25 mainstream teachers) from two primary schools. The results showed that special education teachers and mainstream teachers agreed that social communication skill need to acquire by student were social interaction ability, verbal communication ability, non-verbal communication ability and speech ability. Whereas, showed different view on the importance of social communication to be assessed in student disabilities. For social interaction ability, were agreed, verbal communication ability, non-verbal communication ability and speech ability. Overall results is shown in Fig. 1. 


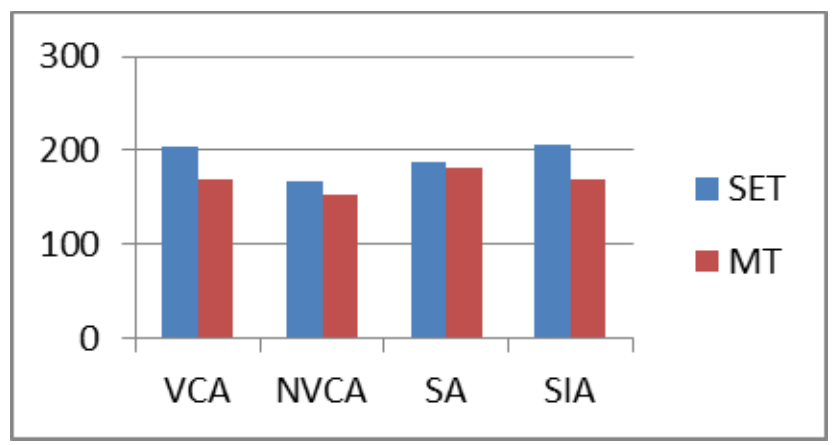

Fig. 1: Social communication skills

Fig. 1 showed the view from special education teachers (SET) and mainstream teachers (MT). Finding showed that total view for each abilities were 375 (26.13\%) for social interaction ability (SIA), 373 (25.99\%) for verbal communication ability (VCA), 368 (25.64\%) for speech ability (SA), and 319 (22.23\%) for non-verbal communication (NVCA). Social communication skills should be determined as one of the criteria for the purposes of selection of student in inclusive program. As a comparison between two groups, SET strongly agreed with the suggested skills which is need to be assessed on student with disabilities for placement in the inclusive education. According to SET, the first importance skill was an ability in social interaction ability (14.29\%), verbal communication ability (14.15\%), speech ability (13.03\%) and non-verbal communication (11.64\%). View from MT was quite highly different from SET group but both agreed that the most importance social communication skills must be acquired by student with disabilities was speech ability (12.61\%), social interaction ability was $(11.85 \%)$, verbal communication ability $(11.85 \%)$, and non-verbal communication (10.59\%).

\section{Criteria 1 : Social interaction ability (SIA)}

The most importance social communication skill were social interaction and finding showed that $\mathbf{7 5 . 0 0 \%}$ participants agreed to put social interaction ability in the first place to select student for inclusion compared to other skills. Result for social interaction ability is shown in Figure 2.

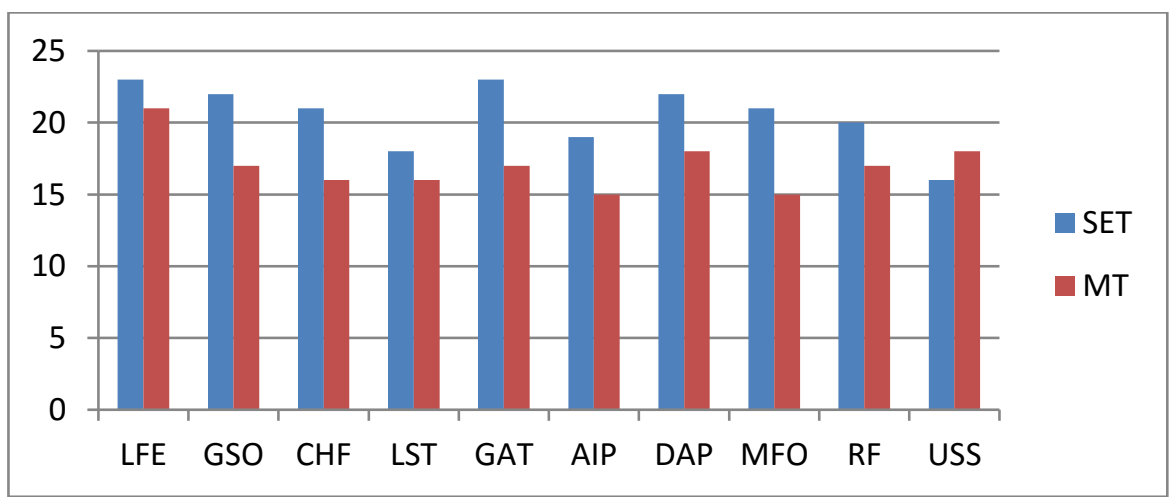

Fig. 2 Social interaction ability 
Figure 2 showed that $41.00 \%$ special education teachers and $34.00 \%$ mainstream teachers agreed that (SIA) were the most importance skill to be acquired by student with disabilities for placement in the inclusive education. Out of 10 abilities, the highest skill to be considered in placement of student was an ability to 'look at face and eyes when talk with someone' (LFE). 44 participants were agreed that 'look at face and eyes when talk with someone (LFE)' is important during social interaction with others and must take in to consideration in selection of student for inclusion. It is followed by 'give attention when talk with someone/GAT (40), do activity with peers/DAP (40), give smile to others/GSO (39), recognize friend/RF (37), can make friend with others/MFO (36), clap hands when friend answer correctly/CHF (35), look somewhere else when talking/LST (34), accept invitation to play together/AIP (34), and understand social situation/USS (34)'. The last three abilities (LST, AIP, USS) were not strongly agreed by participants to be considered as an assessment criteria in social communication skill.

\section{Criteria 2 : Verbal communication ability (VCA)}

Findings showed that the second importance skill for placement of student in the inclusive program was verbal communication ability (VCA). Result proven that $74.60 \%$ participants were strongly agreed that VCA must be assessed in selecting student for inclusion. Figure 3 showed the finding for verbal communication ability from teachers' view.

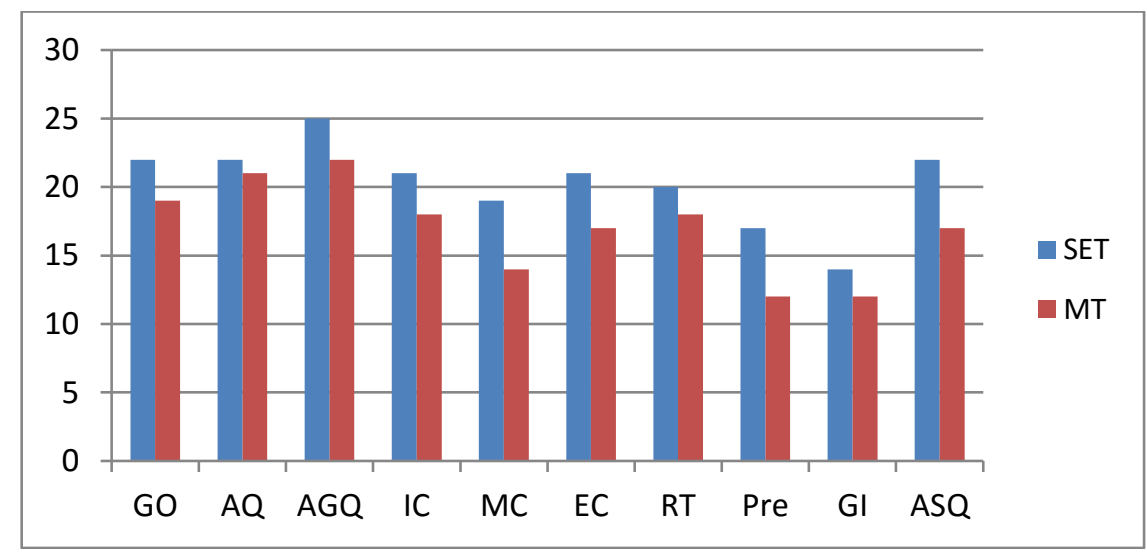

Fig. 3 Verbal communication ability

It is clear that $40.60 \%$ special education teachers and $34.00 \%$ mainstream teachers were supported for VCA to be one of the criteria for placement of student in the program. The most importance VCA in the social communication skill was 'answer general question' (AGQ). 47 participants were agreed that an 'ability to answer question' is one of the skill that need to be considered for selection of student in the inclusive program. It is followed by an ability to ask question/AQ (43), giving opinion/GO (41), initiating conversation/IC (39), answer specific question/ASQ (39), ending conversation/EC (38), review topic/RT (38), maintaining conversation/MC (33), Predict/Pre (29), and giving instruction/GI (26). 26 participants were agreed that GI (giving instruction) is not necessarily to be considered in selecting student for inclusion. In addition, with limited knowledge in language, student faced difficulties in arranging communication with others.

Criteria 3 : Speech ability (SA) 
INTERNATIONAL JOURNAL OF ACADEMIC RESEARCH IN BUSINESS AND SOCIAL SCIENCES

Vol. 10, No. 3, March, 2020, E-ISSN: 2222-6990 (C) 2020 HRMARS

Speech ability (SA) was the third importance of social communication skill that need to look for placement of student with disabilities in the inclusive program. $73.60 \%$ participants supported the used of speech ability as a criteria for placing student in the inclusive classroom. Finding for speech ability is shown in Figure 4.

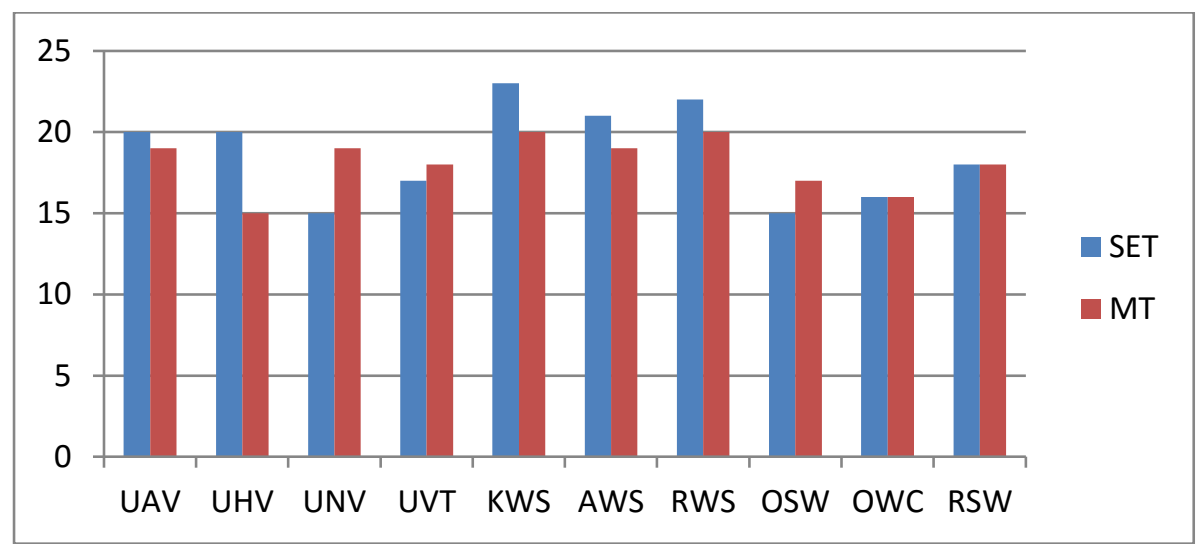

Fig. 4 Speech ability

Result was showed that $37.40 \%$ of special education teachers were strongly agreed that speech ability was important to refer for selecting student in the inclusive program. The most important skill in speech ability was 'knowing word to speak/KWS (43)' and 'remember word to speak/RWS (42). Student with disabilities should have word in mind in order to have conversation with others. Without word in mind they can't speak well and were always misunderstood by people around them. Other abilities in speech were identified as 'use accurate word when speak/AWS (40), use appropriate voice intonation when speak/UAV (39), repeat same word/RSW (36), understand voice tone/UVT (35), use high voice tone in noisy situation/UHV (35), use normal voice tone in formal situation/UNV (34), omit syllables in word/OSW (32) and omit first or last word in conversation/OWC (32). Students with disabilities were frequently do mistake in speech especially in omitting syllable when speak because they can't remember the word to speak accurately. And they also had problems in pronunciation in some words which is not familiar to them or the word is a bit long.

Criteria 4 : Non-verbal communication ability (NVCA)

Social communication skills also included non-verbal communication. This ability was the lowest skill to be assessed in selection of student for inclusion. Nevertheless $63.80 \%$ participants agreed that non-verbal communication ability was among the skills that need to give attention in selection of student for inclusion. It is true that when people do not speak they will used non-verbal to communicate or to interact with other such as finger, head, or body language. Figure 5 showed the importance of non-verbal communication ability for selection of student in the inclusive setting. 
INTERNATIONAL JOURNAL OF ACADEMIC RESEARCH IN BUSINESS AND SOCIAL SCIENCES Vol. 10, No. 3, March, 2020, E-ISSN: 2222-6990 @ 2020 HRMARS

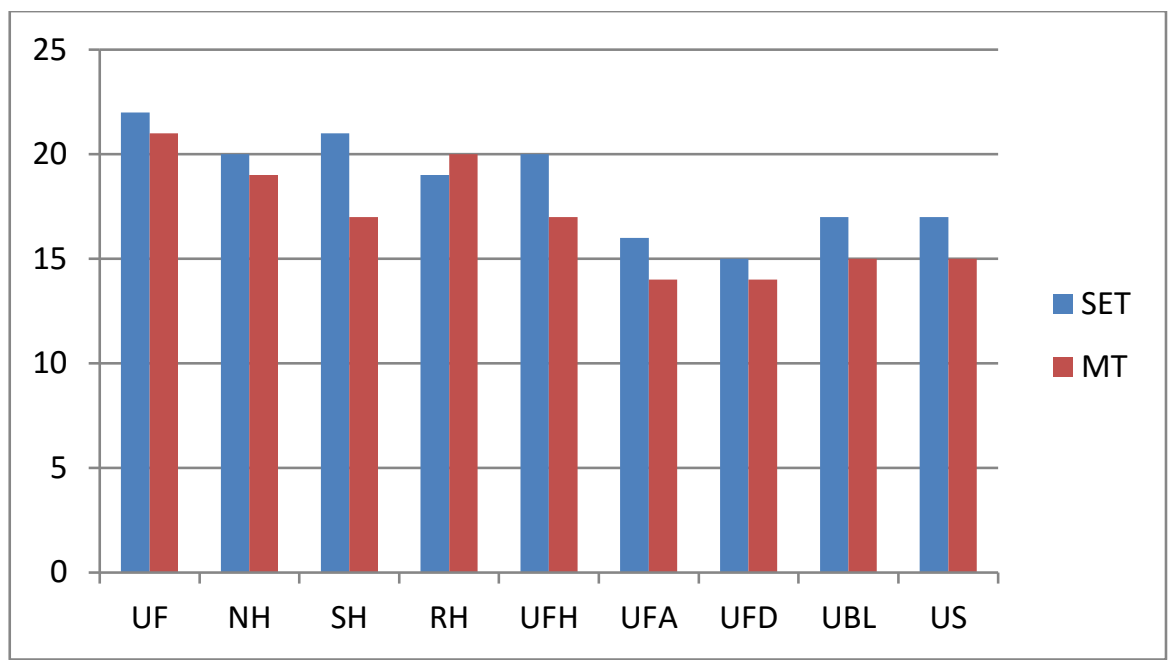

Fig. 5 Non-verbal communication ability

Finding showed that $37.11 \%$ special education teachers and $33.78 \%$ mainstream teachers were supported the skill for selecting student in inclusive program. The most important ability in nonverbal communication was 'use finger to show things correctly/UF (43)'. Beside that the non-verbal communication also involved nod head to show understanding/ $\mathrm{NH}$ (39), raise hand to say something/RH (39), shake head when not understand/SH (38), understand facial expression of happiness/UFH (37), use body language to communicate/UBL (32), use sign or symbol to say something/US (32), understand facial expression of angry/UFA (30), and understand facial expression of dislike/UFD (29). Non-verbal communication is commonly used by student with disabilities in social interaction whenever they could not use language to communicate. This skill should be taken in to consideration when selecting student for inclusion.

\section{Discussion}

Social communication skill is an important criteria to be acquired by students for successful inclusion in school. This skill is a compulsory skill for student with disabilities to be accepted in inclusive program. Besides academic performance, students must have an ability to communicate as well to be socialized with typical students and in different learning environment. To acquire skill ini social communication, student must be exposed to systematic learning or training program such as verbal and non-verbal communication, speech ability and social skills. Teaching appropriate social skills and providing opportunities and experiences that can increase social interactions enables students to practice and apply social strategies and skills in actual environments and life situations (Morgan et al., 2015). This present study showed an evident that providing these types of skills is the responsibility of all people especially the teachers, who are interacting with these students and requires programs of social communication training.

The placement of student in inclusive program is depends on various criteria such as academic performance, learning behavior, attitude, facilities in school and the most important is the social communication skills. However, because of the increasing changes and complexities of society, developing social communication and preparing student with disabilities for inclusion, seem essential to counter difficult positions. All students with need to learn appropriate social skills (Agran et al., 
2016; Davies., Cooper., Kettler., \& Elliott, 2015; Rawles, 2016). By giving them a chance to develop skills in social communication, they will have more opportunities to be placed in inclusive program. Student with disabilities must be well trained in verbal and non-verbal communication as a preparation for them to get along with peers and teachers in the inclusive classroom and could be done in teaching and learning process. The Salamanca statement (1994) states that the curricula should be adapted to the students' needs, so in order to develop social communication skills, teachers could modify the learning activity according to their ability. Celebrating diversity and valuing student with special needs are problems within schools and make inclusion impossible (Göransson, Nilholm, \& Karlsson 2011). With the appropriate skill in social, communication and speech ability, they are able to adapt with others in comfortable situation. Besides that they will be accepted as a member in the community as well. The influence of social communication skill for placement of student with disabilities for inclusion should be investigated. The influence of these types of skills on improving students' performance should be studied. Social communication skill training may be considered in in-service training programs for teachers and in knowledge-increasing programs for parents until they can play the required role in making the students compatible and improving their social communication performance.

\section{Conclusion}

Placing student in the inclusive education is depends on many factors. Teachers' understanding of including students with a variety of special educational needs (SENs) is of great importance for a successful implementation of inclusion, which also is emphasized in the Salamanca Statement (UNESCO, 1994). Not only in an academic achievement, the requirement in placement student also have to look at their social communication skills. The main criteria for social communication skill have to be based on verbal communication, non-verbal communication, and social interaction. Social communication is important in learning process, even curriculum in school also rely on communication between peers. Hence, research on placement of student with disabilities in the inclusive classroom is necessarily to be carried out by researchers in various field to be in line with Salamanca.

\section{Acknowledgement}

The authors would like to express their highest gratitude to the Ministry of Higher Education Malaysia for the funding of this research project (Fundamental Research Grant Scheme /FRGS) via code number FRGS/1/2017/SSI09/UPSI/02/12.

\section{Corresponding Author}

Norfishah Mat Rabi,

Faculty of Human Development, Universiti Pendidikan Sultan Idris, Malaysia

Email: norfishah@fpm.upsi.edu.my 
INTERNATIONAL JOURNAL OF ACADEMIC RESEARCH IN BUSINESS AND SOCIAL SCIENCES

Vol. 10, No. 3, March, 2020, E-ISSN: 2222-6990 @ 2020 HRMARS

\section{References}

Agran, M., Hughes, C., Thoma, C. A., \& Scott, L. A. (2016). Employment Social Skills: What Skills Are Really Valued? Career Development and Transition for Exceptional Individuals, 39(2), 111-120.

Smith, A., Prendeville, P., \& Kinsella, W. (2018). Using preferred interests to model social skills in a peer-mentored environment for students with special educational needs. International Journal of Inclusive Education, 22:8, 921-935, DOI: 10.1080/13603116.2017.1412516.

Atashak, M., Baradaran, B., \& Ahmad, V., \& M. A. (2013). The Effect of Educational Computer Games on Students' Social Skill and Their Educational Achievement. Journal of Technology of Education, 7(4), 297-305.

Barton, E. E., \& Pavilanis, R. (2012). Teaching pretend play to young children with autism. Young Exceptional Children, 15(1), 5-17.

Bjornsrud, H., \& Nilsen, S. (2011). The development of intentions for adapted teaching and inclusive education seen in light of curriculum potential - A content analysis of Norwegian national curricula post 1980. Curriculum Journal, 22(4), 549-566.

Davies, M., Cooper, G., Kettler, R. J., \& Elliott, S. N. (2015). Developing Social Skills of Students with Additional Needs within the Context of the Australian Curriculum. Australasian Journal of Special Education, 39(1), 37-55.

De Bortoli, T., Arthur-Kelly, M., Mathisen, B., \& Balandin, S. (2014). Speech-Language Pathologists' Perceptions of Implementing Communication Intervention with Students with Multiple and Severe Disabilities. AAC: Augmentative \& Alternative Communication, 30, 55-70.

de Boer, A., S. J. Pijl, \& A. Minnaert. (2011). Regular Primary Schoolteachers' Attitudes towards Inclusive Education: A Review of the Literature. International Journal of Inclusive Education 15 (3): 331-353. doi: 10.1080/13603110903030089.

Erozkan, A. (2013). The Effect of Communication Skills and Interpersonal Problem Solving Skills on Social Self-Efficacy. Educational Sciences: Theory \& Practice, 13(2), 739-745.

Ferraioli, S. J., \& Harris, S. L. (2011). Effective educational inclusion of students on the autism spectrum. Journal of Contemporary Psychotherapy, 41(1), 19-28.

Flook, L., Goldberg, S. B., Pinger, L., \& Davidson, R. J. (2015). Promoting prosocial behavior and selfregulatory skills in preschool children through a mindfulness-based Kindness Curriculum. Dev Psychol, 51(1), 44-51.

Göransson, K., C. Nilholm, \& K. Karlsson (2011). Inclusive Education in Sweden? A Critical Analysis. International Journal of Inclusive Education, 15 (5): 541-555. doi: 10.1080/13603110903165141.

Gresham, F. M. (2016). Social Skills Assessment and Intervention for Children and Youth. Cambridge Journal of Education, 46(3), 319-332.

Sakiz, H. (2018). Students with learnin g disabilities within the context of inclusive education: issues of identification and school management, International Journal of Inclusive Education, 22:3, 285305, DOI: $10.1080 / 13603116.2017 .1363302$

Hedegaard Hansen, J. (2012). "Limits to Inclusion." International Journal of Inclusive Education 16 (1): 89-98. doi: 10.1080/13603111003671632.

Karakaya, E. G., \& Taufan, M. (2018). Social Skills, Problem Behaviors and Classroom Management in Inclusive Preschool Settings. Journal of Education and Training Studies, 6(5).

Kasari, C., Chang, Y. C., \& Patterson, S. (2013). Pretending to play or playing to pretend: the case of autism. American Journal of Play, 6(1), 124. 
INTERNATIONAL JOURNAL OF ACADEMIC RESEARCH IN BUSINESS AND SOCIAL SCIENCES

Vol. 10, No. 3, March, 2020, E-ISSN: 2222-6990 @ 2020 HRMARS

Lee, S. Y., Olszewski-Kubilius, P., Makel, M. C., \& Putallaz, M. (2015). Gifted students' perceptions of an accelerated summer program and social support. Gifted Child Quarterly, 59, 265-282.

Lillard, A. S., Lerner, M. D., Hopkins, E. J., Dore, R. A., Smith, E. D., \& Palmquist, C. M. (2013). The impact of pretend play on children's development: a review of the evidence. Psychological Bulletin, 139(1), 1.

Loreman, T., Deppler, J., \& Harvey, D. (2005). Inclusive Education: A Practical Guide to Supporting Diversity in the Classroom. Routledge Falmer, London and New York.

Morgan, J., Hsiao, Y. J., Dobbins, N., Brown, N., \& Lyons, C. (2015). An Observation Tool for Monitoring Social Skill Implementation in Contextually Relevant Environments. Intervention in School and Clinic, 51(1), 3-11.

Naraian, S., Ferguson, D. L., \& Thomas, N. (2012). Transforming for Inclusive Practice: Professional Development to Support the Inclusion of Students Labelled as Emotionally Disturbed. International Journal of Inclusive Education, 16 (7): 721-740. doi: 10.1080/13603116.2010.509817.

Nix, R. L., Bierman, K. L., Domitrovich, C. E., \& Gill, S. (2013). Promoting children's social-emotional skills in preschool can enhance academic and behavioral functioning in kindergarten: findings from Head Start REDI. Early Education \& Development, 24(7), 1000-1019.

Rawles, J. (2016). Developing Social Work Professional Judgment Skills: Enhancing Learning in Practice by Researching Learning in Practice. Journal of Teaching in Social Work, 36 (1), 102-122.

Spratt, J., \& Florian, L. (2013). Applying the principles of inclusive pedagogy in initial teacher education: from university based course to classroom action. Revista de Investigation en Education, 11(3), 133-140.

UNESCO. (1994). The Salamanca Statement and Framework for Action on Special Needs Education. Paris: UNESCO.

Gidlund, U. (2018). Why teachers find it difficult to include students with EBD in mainstream classes. International Journal of Inclusive Education, 22:4, 441-455, DOI: 10.1080/13603116.2017.1370739.

Walker, O. L., \& Henderson, H. A. (2012). Temperament and social problem solving competence in preschool: influences on academic skills in early elementary school. Social Development, 21(4), 761- 779.

Wright, C., Diener, M. L., \& Kemp, J. L. (2013). Storytelling dramas as a community building activity in an early childhood classroom. Early Childhood Education Journal, 41(3), 197-210. 